\title{
ANTI-COLLAGEN TYPE IV ANTIBODIES AND THE DEVELOPMENT OF MICROVASCULAR COMPLI- CATIONS IN DIABETIC PATIENTS WITH ARTERIAL HYPERTENSION
}

\author{
Asparuh G. Nikolov ${ }^{1}$, Georgi Nicoloff ${ }^{2}$, Ivan Tsinlikov ${ }^{1}$, Ivanka Tsinlikova ${ }^{1}$, \\ 1) Department of Propedeutics of Internal Diseases, Medical University, Pleven \\ 2) Division of Biology, Medical University, Pleven, Bulgaria.
}

\section{S UMMARY}

Background and Aims: Thickening of basement membrane in capillaries and small vessels is a well-known finding and important in the progression of diabetic microangiopathy. Patients with diabetes mellitus and arterial hypertension are at higher risk of vascular disease.

Material and methods: To monitor the metabolism of the basement membrane protein collagen type IV (CIV) in type 2 diabetes mellitus (T2DM), serum levels of antibodies to CIV (ACIV) IgG, IgM and IgA were measured using an ELISA method in 93 patients with type 2 diabetes mellitus and arterial hypertension (AH) (mean age 61,4 11,3 years, diabetes duration 9,88 $\pm 3,12$ years; hypertension duration $9,28 \pm 4,98)$. These values were compared to serum antibodies to CIV in 42 age and sex matched controls. Diabetics were divided in two groups according to presence- Group $1(n=67)$ or absence- Group 2 ( $\mathrm{n}=26)$ of microangiopathy.

Results: Patients with $\mathrm{T} 2 \mathrm{DM}$ and $\mathrm{AH}$ showed statistically significant higher levels of ACIV IgG in comparison to healthy controls $(0.30 \pm 0.12$ vs. $0.21 \pm 0.08)$ $(\mathrm{p}=0.0001)$. Group 1 showed significantly hihger levels of ACIV IgG than Group $2(0.32 \pm 0.13 v s .0 .24 \pm 0.08)(\mathrm{p}=0.009)$ and healthy controls $(0.32 \pm 0.13 \mathrm{vs} .0 .21 \pm 0.08)(\mathrm{p}=0.0001)$. ACIV $\mathrm{IgG}$ are statistically significant higher in diabetics with retinopathy than this without $(0.33 \pm 0.10$ vs. $0.26 \pm 0.13)$ $(\mathrm{p}=0.04)$. ACIV IgG correlates with diabetes duration $(\mathrm{r}=0.49)$; $(\mathrm{p}=0.0004)$, retinopathy $(\mathrm{r}=0.20) ;(\mathrm{p}=0.05)$ and $\mathrm{BMI}(\mathrm{r}=-0.24)$; $(\mathrm{p}=0.05)$. Serum ACIV IgM and IgA levels in patients with $\mathrm{T} 2 \mathrm{DM}$ and $\mathrm{AH}$ were lower than these in controls, but the differences are not statistically significant.

Conclusion: Our study showed a relationship between elevation of serum levels of ACIV IgG in diabetics and development of microangiopathy.

Key words: Diabetes mellitus, arterial hypertension, anti-collagen type $\operatorname{IgG}$, micrangiopathy

\section{INTRODUCTION}

Clinical manifestations of microvascular and macrovascular involvement in diabetes include retinopathy, nephropathy and accelerated atherosclerosis, possible leading to blindness, renal failure, myocardial infarction, stroke and limb amputation. These target organ manifestations show common pathological characteristics underlying all vascular diseases; however, each complication also has some specific features depending on the tissue (s) involved, with important implications for prevention and treatment Mario and Pugliese, 2001 [1]. This diversity is supported by the distinct epidemiological characteristics of vascular complications, which occur with a different prevalence in diabetic subjects Toeller et al. 1999, Laasko 1999 [2]. The incidence of vascular complications also varies with the site involved. Macroangiopathy is sometimes present at the time of diagnosis, particularly in type 2 (non-insulin-dependent) diabetes mellitus [2], whereas microvascular disease usually developed several years after the onset of diabetes Krolewski et al. 1987 [3], Hanefeld et al. 1996 [4]. However, while the incidence of retinopathy increases with diabetes duration, that of nephropathy reaches a peak after about 15 years and declines thereafter. The rate of development and the severity of vascular injury are also dependent on the individual background; as a result, some people show only initial lesions, whereas others progress towards end-stage disease, despite a similar degree of metabolic derangement.

Arterial hypertension and diabetic vascular complications are connected with an elevated degradation of elastic tissue. As a result collagen type IV (CIV) are released in the circulated blood, which are a pathological stimulus for an increased production of antibodies to CIV (ACIV). Because it is very important to find characteristics of pathological activation of collagen turnover in diabetics we studied diabetic patients with arterial hypertension who demonstrated vascular complications.

In diabetes mellitus, thickening of basement membrane in capillaries and small vessels is a well-known finding and important in the progression of diabetic microangiopathy. Collagen type IV is uniquely present in basement membranes and represents their predominant structural element Paulsson 1992 [5], Kuhn 1995 [6]. Metabolic alteration of CIV occurs in micro- or 
macrovascular basement membrane of diabetic patients.

Elastin and collagen are the main proteins of vascular wall. An important factor in the development of vascular wall alterations is degradation of the extracellular matrix 's major protein - collagen Rosenbloom et al., 1993 [7]. Basement membranes regulate the functions of many cells and mediate the interactions between different tissues Paulsson, 1992 [5]; Kuhn 1995 [6]. Collagen type IV constitutes the major component of basement membranes Schuppan and Riecken, 1990 [8]. Measurement of serum antibodies to fragments of CIV Balashova et al., 2000 [9]; Nicoloff et al., 2002 [10] is now possible and enables changes to be detected.

Because collagen type IV is uniquely present in basement membranes and represents their predominant structural element $[6,8]$ several immunological methods for detection of circulating CIV were developed Risteli L. Et al. 1987 [11]. The detection of circulating CIV in the serum of diabetic subjects Alland A, Matsumoto E, Nicoloff G [12, 13, 14] shows that the CIV macromolecule is not fully degraded by collagenases in vivo. These CIV may become a stimulus for immunocompetent cells and result in the production of anti-CIV antibodies.

There is data for detection of serum CIV in animals or humans with arterial hypertension Hasslacher et al., 1987 [15]; Yano et al., 1997 [16]. These CIV fragments may become an increased stimulus for immunocompetent cells for pathological production of anti-CIV antibodies.

Investigators Susumu et al, 2003 [20] measured serum anti-type IV collagen antibody (IgG) in diabetic patients and they found that serum levels of the anti-type IV collagen antibody were significantly higher in diabetics than these in the nondiabetics. However, there was no relationship between the levels of urinary albumin and the serum levels of antitype IV collagen antibody.

We investigated anti-collagen type IV antibodies in children with essential hypertension and patients showed significantly higher levels of collagen type IV IgM while collagen type IV IgG levels were lower than these in controls Nicoloff et al, 2006 [21].

In the present investigation we studied whether the serum levels of antibodies (IgG, IgM and IgA) to type IV collagen are related with the presence of diabetic microangiopathy. This study establishes normal serum levels of ACIV in healthy subjects and compares them to these of patients with diabetes mellitus and arterial hypertension. The changes observed are correlated with diabetic microvascular complications.

\section{MATERIALAND METHODS}

Subjects

The experimental group consisted of 93 patients ( 37 men, 56 women) with type 2 diabetes mellitus and arterial hypertension (mean age 61,4 $\pm 11,3$ years, diabetes duration $9,88 \pm 3,12$ years; hypertension duration $9,28 \pm 4,98$ ). These values were compared to serum antibodies to CIV in 42 age and sex matched controls with no family history of diabetes, atherosclerosis or emphysema. The controls were equally distributed to match the diabetic ages. Diabetics were divided in two groups according to presence- Group $1(n=67)$ or absence- Group $2(n=26)$ of microvascular complications (Table 1). Group 1 cosisted of $39 \%$ men and $61 \%$ women. Fiftyfive percent were smokers and $45 \%$ non-smokers. Group 2 consisted of $42 \%$ men and $58 \%$ women. Fifty-eight percent were smokers and $42 \%$ non-smokers. Controls consisted of $45 \%$ men and $55 \%$ women. Twenty-seven percent were smokers and $73 \%$ non-smokers (Table 2). Microalbuminuria was defined as a persistent urinary albumin excretion rate (AER) in the range of 20 and $200 \mu \mathrm{g} / \mathrm{min}$ in sterile urine. None of the patients had a diagnosis of renal disease unrelated to diabetes during the follow up.

\section{Clinical draft}

All patients were residing in the vicinity of the Pleven University Hospital. Subjects' sera were taken from October 2011 to May 2012. Ethical approval was obtained from the local research ethics committee and all subjects gave an informed written consent prior to the study.

Procedure

Serum antibodies (IgG, IgM and IgA) to CIV were measured by an enzyme-linked immunosorbent assay (ELISA). In brief, each well of the microtiter plate was sensitized with $100 \mu \mathrm{l}$ of $10 \mu \mathrm{g} / \mathrm{ml}$ of human CIV (SIGMA, USA) at room temperature for $3 \mathrm{~h}$, followed by an overnight incubation at $4 \mathrm{oC}$. The plate was washed with phosphatebuffered saline (PBS) containing 0.05\% Tween 20 and $1 \%$ bovine serum albumin (BSA, SIGMA, USA). Then, $100 \mu 1$ serum sample (diluted 1:10), was placed in each well of a microtiter plate, and incubated for $1 \mathrm{~h}$ at $37^{\circ} \mathrm{C}$. After washing three times, $100 \mu 1$ of immunoconjugates (anti-human immunoglobulin peroxidase conjugates (SIGMA, USA) to heavy chain of $\operatorname{IgG}, \operatorname{IgM}$ and $\operatorname{IgA}$ ) were added to each well for $1 \mathrm{~h}$ at $37^{\prime} \mathrm{C}$. All immunoconjugates were diluted 1:10,000 with PBS containing $1 \%$ BSA and $0.05 \%$ Tween 20 . The plate was incubated for $1 \mathrm{~h}$ at $37^{\circ} \mathrm{C}$. o-Phenylenediamine $(0.4 \mathrm{mg} /$ $\mathrm{ml}$ ) was added to citrate buffer, and $100 \mu \mathrm{l}$ of this solution was added to each well and allowed to react for $30 \mathrm{~min}$. The reaction was stopped by adding $50 \mu 14 \mathrm{M} \mathrm{H} 2 \mathrm{SO} 4$ to each well and the optical density was measured with a Microelisa Reader 210 (Organon Teknika, Belgium) at a wavelength of $492 \mathrm{~nm}$. Anti-CIV levels greater than the mean $\pm 2 \mathrm{SD}$ of the healthy controls were designated positive.

Ophthalmoscopy through dilated pupils was carried out in all patients with diabetes mellitus to assess the presence of retinopathy; all patients were examined by the same ophthalmogist. Hemoglobin A1c was measured using high-pressure liquid chromatography (normal range 4-6\%). Total serum cholesterol and triglyceride concentrations were measured by enzyme assay (Boehringer Mannheim, Mannheim, Germany). Arterial blood pressure was measured 
using a standard mercury sphygmomanometer, to the nearest $2 \mathrm{~mm} \mathrm{Hg}$, in the dominant arm after at least 10 min rest in the supine position. AER was determined by nephelometry using a commercial kit containing specific antibody (Behringwerke, Marburg, Germany).

Statistical analyses

All values are expressed as mean \pm SD. Statistical analyses were done using the computer programs EXCEL and STATGRAPHICS plus for WINDOWS. The Student t-test and ANOVA were used to assess the differences between groups. Correlation and regression analyses were also used. The level of significance was determined as $\mathrm{p}<0.05$.

\section{RESULTS}

Patients with T2DM and AH showed statistically significant higher levels of ACIV IgG in comparison to healthy controls $(0.30 \pm 0.12$ vs. $0.21 \pm 0.08)(\mathrm{p}=0.0001)$. Group 1 showed significantly hihger levels of ACIV IgG than Group $2(0.32 \pm 0.13$ vs. $0.24 \pm 0.08)(\mathrm{p}=0.009)$ and healthy controls $(0.32 \pm 0.13$ vs. $0.21 \pm 0.08)(\mathrm{p}=0.0001)$. Group 2 showed higher levels of ACIV IgG than controls $(0.24 \pm 0.08$ vs. $0.21 \pm 0.08)$ $(\mathrm{p}=0,05)$. ACIV IgG correlates with diabetes duration $(\mathrm{r}=0.49)$; $(\mathrm{p}=0.0004)$, retinopathy $(\mathrm{r}=0.20) ;(\mathrm{p}=0.05)$ and $\mathrm{BMI}(\mathrm{r}=-0.24)$; $(\mathrm{p}=0.05)$ (Table 3, Fig. 1). All diabetic patients $(\mathrm{n}=93)$ were divided in two subgroups depending on data for diabetic retinopathy: patients with retinopathy $(\mathrm{n}=20)$ and patients without retinopathy $(n=73)$ according to European Association for the Study of Diabetes (EASD) Classification. Levels of ACIV IgG are statistically significant higher in diabetics with retinopathy than this without $(0,33 \pm 0,10$ vs. $0,26 \pm 0,13)(p=0.04)$ (Table 4, Fig. 2).

Serum ACIV IgM and IgA levels in patients with T2DM and $\mathrm{AH}$ were lower than these in controls, but the differences are not statistically significant (Table 5 and 6).

\section{DISCUSSION}

Epidemiological studies have shown a strong relationship between obesity and cardiovascular disease, and between obesity and specific cardiovascular risk factors such as hypertension and diabetes mellitus. In diabetic patients morbidity and mortality are mainly related to the presence of late complications, namely macro- and microangiopathy. Diabetes mellitus (both Type 1 and Type 2) is a major risk factor for cardiovascular disease. In the Framingham Study, the risk of cardiovascular disease was doubled by the presence of diabetes The Framingham study 1979 [17].

Collagens are known to be immunogenic in animals, and antibodies to various collagens are present in human serum in several diseases, particularly those of autoimmune origin Moreland et al., 1991 [18]; Yang et al., 1993 [19]; Daskalova et al., 1997 [22]. The detection of serum CIV in animals or humans with arterial hypertension Hasslacher et al., 1987 [15]; Yano et al., 1997 [16] shows that CIV macromolecule is not fully degraded by collagenases in vivo.
These CIV fragments may become an increased stimulus for immunocompetent cells for pathological production of antiCIV antibodies. Changes in the levels and pattern of antibodies to CIV may occur with time.

Type IV collagen, which is one of the major constituents of basement membranes and fibrous tissue, is composed of a $7 \mathrm{~S}$ collagen domain formed by four aminoterminal ends linked together in an antiparallel arrangement, and a globular carboxyterminal cross linking domain Sato et al., 1997 [23]. Four or five collagen molecules, lenghtwise disposed and linked with glycoproteins, form collagen microfibrile Stanley RG, 2009 [24]. Collagen catabolism is not fully studied rather than its synsthesis Labasse A, 2007 [25]. Collagen catabolism is a complex and multistage process, running not only at intracellular level, but also at extracellular matrix. Intracellular collagen destruction starts with activation of highly specific collagenase, which interacts with collagen molecules Weis et al, 2001 [26].

The object of the study of Yano et al. 1997 [16] was to evaluate the serum $7 \mathrm{~S}$ domain of type IV collagen (7Scollagen) levels in patients with essential hypertension and in type 2 diabetic patients with or without hypertension and to investigate the relationship between the type IV collagen metabolism and the arterial blood pressure. Serum 7S-collagen levels in 18 patients with essential hypertension were significantly higher than in 24 normal subjects. There was a significant correlation between the serum 7S-collagen levels and the systolic blood pressure in cases with essential hypertension. In a recent study we measured levels of ACIV antibodies in patients with diabetes mellitus and arterial hypertension. Patients with microvascular complications showed significantly higher levels of ACIV IgG in comparison with other groups. Patients with type 2 diabetes mellitus are at high risk of diabetic microangiopathy and vascular disease. The angiopathic complications usually developed after several years of type 2 diabetes Klein et al. 1984 [27]. In the present study, we found a significant relationship between serum levels of ACIV IgG and development of diabetic retinopathy.

One possible explanation is that the first immunoglobulin synthesised during the early phase of a pathologically activated immune response is IgM. The immune system then switches on to producte IgG. The elevation of ACIVAbs of the IgM is therefore the first indicator of the pathological turnover of collagen and the development of microvascular complications. Since the cells responsible for the cell-mediated immune response (phagocytes, T-effector cells, NK-cells, etc) have more receptors for the Fc-fragments of IgM, they will react preferentially with immobilized and soluble immune complexes formed with IgM ACIV Abs. The presence of ACIV Abs could lead to a variety of pathological processes including immune complexes formation.

We found that ACIV IgG are statistically significant 
higher in diabetics with retinopathy. Probably, patients developed microangiopathy before our detection and they are not in the very early phase of microvascular disease. The elevation of anti-CIV of IgG type is therefore the next indicator of the pathological turnover of CIV.

There is evidence that proteins, including immunoglobulins, accumulate in the matrix lining the walls of small blood vessels in diabetic subjects Brownlee et al. 1983 [28]. IgG binds preferentially to basement membranes, which contain AGE Brownlee et al. 1993 [29]. Prolonged hyperglycaemia results in irreversible cross-linkage of collagen containing AGE Airaksinen et al. 1993 [30]. Immunoglobulins bind to collagen-AGE complex, increasing attachment sites for other proteins and expanding the matrix. Macrophages react with new epitopes on CIV molecule (CIV with AGE) and release monokines, tumor necrosis factor and interleukin-1. The last is an increased non-specific pathological stimulus for production of more anti-CIV IgG, which will react with the new epitopes and may be, will crossreact with "normal "epitopes of CIV molecule. Glycation of basement membrane CIV is a major process leading to diabetic microvascular complications. Increased synthesis or increased degradation could cause the elevated serum levels of CIV which are strong pathological stimulus for production of specific antibodies found in our study, mainly in the patients with retinopathy.

S. Tisheva founds that in pre-hypertension patients compared to healthy persons, quantities of elastin degradation peptides were significantly increased. This is a character of an accelerated elastolisa, and the changes happen before hypertension determination. In modarate arterial hypertension persons, elastin turnover is disbalanced. Increased EDP quantities and high levels of anti-elastin antibodies can be stated. AH patients compared to pre-hypertension patients and controls, the constellation of significantly higher EDP quantities and IgA-antielastin antibodies levels, of IgA-collagen type IV antibodies, of IgG collagen type I and of IgG collagen type III antibodies, is a destroyed integrity sign of fibril structures of vessel wall, 2004 [34].

E. Mekenyan investigates elastin and collagen turnover in patients with metabolic syndrome and founds correlation between anti-elastin, anti-tropoelastin and collagen type IV IgG antibodies and serum triglycerides levels and correlation between anti-AGEs IgG and IgM and triglycerides, which prooves association between vascular aging and athergenic dyslipidemia, characterising metabolic syndrome, 2012 [35].

In our study we found increased serum levels of antiCIV IgG in diabetics with retinopathy. These findings are supported by the results of Balashova et al. 2000 [11] among patients with preclinical, nonproliferative, preproliferative, and proliferative diabetic retinopathy. The authors found that diabetic retinopathy is characterized by a notable increase in antibody-dependent immune response, associated with appearance of antibodies to collagen of the II and IV types in the lachrymal fluid and serum, with the "local" reactions predominating. The level of reactions of cellular autoimmune response (tumor necrosis factor-alpha) and cell-to-cell reactions in the lachrymal fluid and serum was low. According to the authors increased level of circulating immune complexes in the serum and almost complete absence of free antibodies to collagen in the blood may be indicative of formation of pathogenic immune complexes precipitating on vascular walls and in other tissues.

ACIV IgG antibodies showed a significant relationship to diabetes duration and BMI. The elevated mean levels of triglycerides and total cholesterol, out of the normal range, found during the study correlate with the development of diabetic vascular complications as described Steiner, 1997 [31]. It is well known that hypertriglyceridaemia is the most common abnormalities in poorly controlled diabetes.

In our study it was not possible to detect the "active" phase of vascular disease, because of patients"

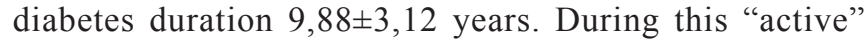
phase the levels of IgM ACIV were probably elevated, while during the chronic phase the levels of this type of ACIV antibody were decreased and only the level of ACIV IgG was increased.

Our study showed a relationship between serum levels of ACIV IgG and development of diabetic retnopathy. The presence of ACIV antibodies could lead to a variety of pathological processes including immune complexes formation, complement activation and $\mathrm{K}$ cell-mediated antibody-dependent cell-mediated cytotoxicity (ADCC) activation, all of which may contribute to the progression of collagen destruction of arterial wall. Furthermore, collagen antigen present at the damaged arterial sites retains selectively antigen specific T- Peterszegi et al. 1997 [32, 33] and B-lymphocytes which would aggravate the response.

Identification of markers would allow more aggressiveness in the achievement of tight glycaemic control and search for initial lesions in those patients who are predisposed to complications than in those who are not. The understanding of the relation between hyperglycemia, the altered pattern of expression of various mediators and the dysregulated vascular remodeling at the level of the target tissue would allow design of therapeutic approach targeted to the individual tissue and to the relevant biochemical, functional and structural alterations.

In conclusion, our results suggest an association between levels of ACIV IgG and the development of vascular wall lesions. Elevation of ACIV IgG may indicate increased collagen degradation and development of microvascular complications. However, a larger study is necessary for clarification of these possibilities. 
Table 1. Clinical data of patients with $\mathrm{T} 2 \mathrm{DM}$ and $\mathrm{AH}$

\begin{tabular}{|l|l|l|l|}
\hline CLINICAL DATA & Group 1 & Group 2 & Controls \\
\hline Age & $62,5 \pm 12,58$ & $60,4 \pm 8,4$ & $58,9 \pm 7,56$ \\
\hline Gender $(\mathrm{M} / \mathrm{F})$ & $26 / 41$ & $11 / 15$ & $10 / 12$ \\
\hline Mean diabetes duration & $9,30 \pm 5,36$ & $9,16 \pm 7,59$ & N/A \\
\hline Mean hypertension duration & $9,50 \pm 7,63$ & $8,68 \pm 7,26$ & N/A \\
\hline HbAlc & $* 7,63 \pm 2,03$ & $7,27 \pm 1,63$ & N/A \\
\hline SBP $(\mathrm{mmHg})$ & $142,83 \pm 18,05$ & $140,58 \pm 20,51$ & $114,29 \pm 15,74$ \\
\hline DBP $(\mathrm{mmHg})$ & $82,23 \pm 11,52$ & $81,35 \pm 11,96$ & $72,5 \pm 10,4$ \\
\hline BMI & $29,62 \pm 4,99$ & $28,42 \pm 3,96$ & $22,61 \pm 2,27$ \\
\hline TCL $(\mathrm{mmol} / \mathrm{l})$ & $* 5,26 \pm 1,40$ & $5,18 \pm 0,93$ & $3,99 \pm 0,65$ \\
\hline HDL $(\mathrm{mmol} / \mathrm{l})$ & $* 0,88 \pm 0,30$ & $0,93 \pm 0,30$ & $0,96 \pm 0,20$ \\
\hline LDL $(\mathrm{mmol} / \mathrm{l})$ & $3,18 \pm 1,19$ & $3,16 \pm 1,09$ & $2,43 \pm 0,64$ \\
\hline TGL $(\mathrm{mmol} / \mathrm{l})$ & $2,91 \pm 1,68$ & $2,53 \pm 1,49$ & $1,31 \pm 0,61$ \\
\hline Insulin dose $(\mathrm{U} / \mathrm{kg} / 24 \mathrm{~h})$ & $2,57 \pm 0,52$ & $2,03 \pm 0,93$ & N/A \\
\hline MAU $(\mu \mathrm{m} / \mathrm{min})$ & $* 78,94 \pm 52,87$ & $8,53 \pm 4,69$ & N/A \\
\hline MAU & $\mathbf{( n = 4 3 )}$ & - & \\
\hline Retinopathy & $\mathbf{( n = 2 0 )}$ & - & \\
\hline Neuropathy & $\mathbf{( n = 4 )}$ & - & \\
\hline Smokers & $37 / 67$ & $15 / 26$ & $16 / 42$ \\
\hline Number & $\mathbf{6 7}$ & $\mathbf{2 6}$ & $\mathbf{4 2}$ \\
\hline
\end{tabular}

Group 1- patients with microvascular complications ( $\mathrm{n}=67$ ); Group 2- patients without microvascular complications $(\mathrm{n}=26) ;$ Controls $(\mathrm{n}=42) \quad$ All Data are Mean \pm SD

Table 2. Percentage of smokers on groups

\begin{tabular}{|l|l|l|l|l|l|}
\hline \multicolumn{2}{|c|}{ Group 1 } & \multicolumn{2}{c|}{ Group 2 } & \multicolumn{2}{c|}{ Controls } \\
\hline Men & Smokers & Men & Smokers & Men & Smokers \\
\hline $39 \%$ & $55 \%$ & $42 \%$ & $58 \%$ & $45 \%$ & $27 \%$ \\
\hline Women & Non-smokers & Women & Non-smokers & Women & Non-smokers \\
\hline $61 \%$ & $45 \%$ & $58 \%$ & $42 \%$ & $55 \%$ & $73 \%$ \\
\hline
\end{tabular}

Table 3. Serum ACIV IgG in patients with T2DM and AH

\begin{tabular}{|l|l|l|l|l|}
\hline \multicolumn{1}{|c|}{ Groups } & \multicolumn{2}{c|}{ ACIV IgG (ng/ml) } & \multicolumn{2}{c|}{ Comparison } \\
\hline & Mean $\pm \mathrm{SD}$ & Group 1 & Group 2 & All diabetics \\
\hline All diabetics & $0.30 \pm 0.12$ & $\mathrm{NS}$ & $\mathrm{P}=0.01$ & - \\
\hline Group 1 & $0.32 \pm 0.13$ & - & $\mathrm{P}=0.009$ & $\mathrm{NS}$ \\
\hline Group 2 & $0.24 \pm 0.08$ & $\mathrm{P}=0.009$ & - & $\mathrm{P}=0.01$ \\
\hline Controls & $\mathrm{P}=0.0001$ & $\mathrm{P}=0.05$ & $\mathrm{P}=0.0001$ \\
\hline
\end{tabular}


Fig. 1. Serum ACIV IgG in patients with T2DM and

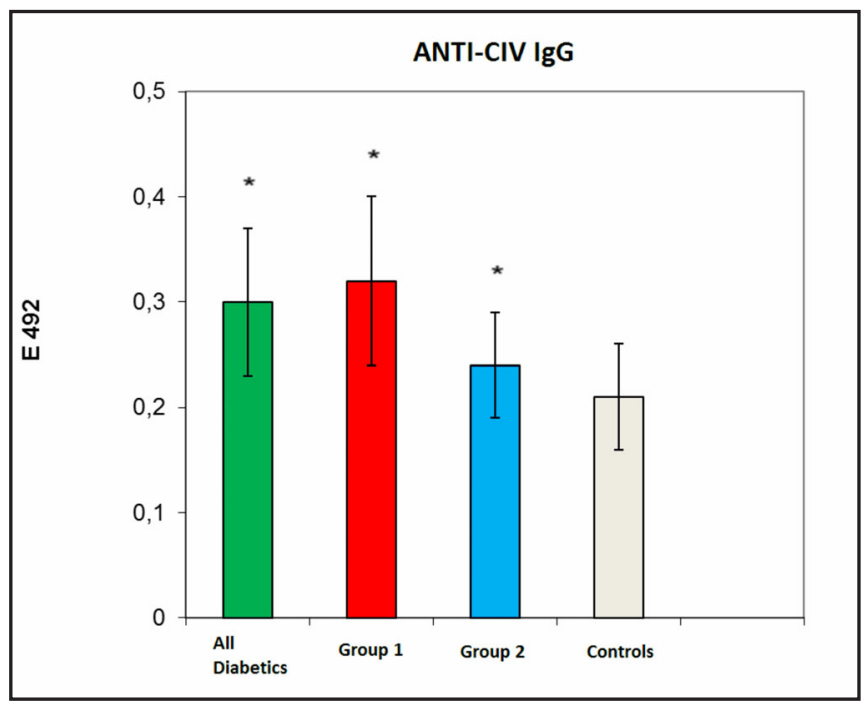

Fig. 2. ACIV IgG are statistically significant higher in diabetics with retinopathy than this without $(\mathrm{p}=0.04)$.

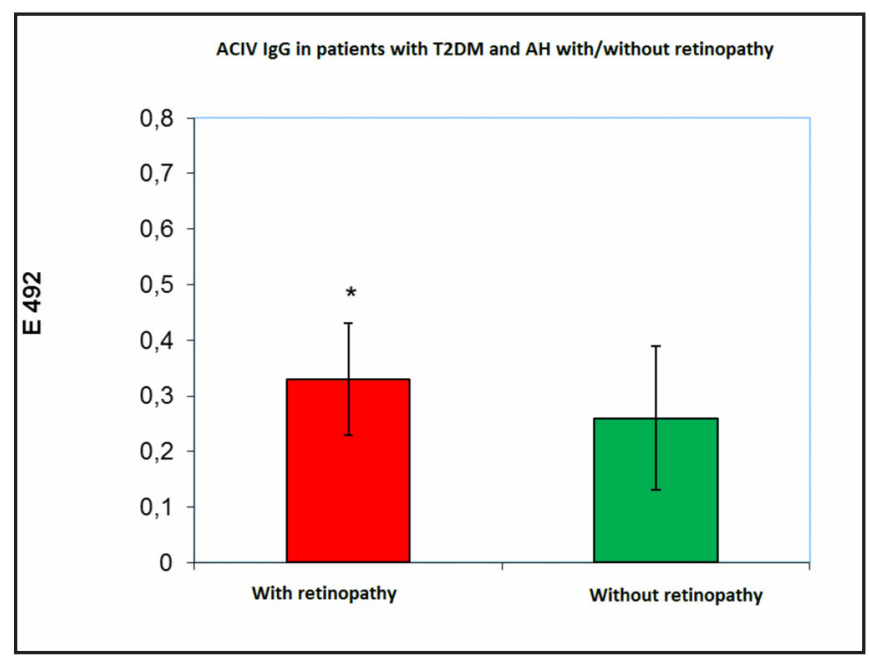

Table 4. Serum ACIV IgG in patients with T2DM and AH. Patients are divided in two subgroups depending on data for diabetic retinopathy

\begin{tabular}{|l|c|c|c|}
\hline & ACIV IgG (ng/ml) & \multicolumn{2}{|c|}{ Comparison } \\
\cline { 3 - 4 } & & (With) & (Without) \\
\hline $\begin{array}{l}\text { With retinopathy } \\
(\mathrm{n}=20)\end{array}$ & $0.33 \pm 0.10$ & - & $\mathrm{P}=0.04$ \\
\hline $\begin{array}{l}\text { Without retinopathy } \\
(\mathrm{n}=73)\end{array}$ & $0.26 \pm 0.13$ & $\mathrm{P}=0.04$ & - \\
\hline
\end{tabular}

Table 5. Serum ACIV IgM in patients with T2DM and AH

\begin{tabular}{|l|c|c|c|c|}
\hline \multicolumn{1}{|c|}{ Groups } & \multicolumn{2}{c|}{ ACIV IgM (ng/ml) } & Group 2 & All diabetics \\
\hline & Mean \pm SD & Group 1 & NS & - \\
\hline All diabetics & $0.18 \pm 0.07$ & NS & NS & NS \\
\hline Group 1 & $0.19 \pm 0.01$ & - & - & NS \\
\hline Group 2 & $0.17 \pm 0.05$ & NS & NS & NS \\
\hline Controls & $0.21 \pm 0.04$ & NS &
\end{tabular}

Table 6. Serum ACIV IgA in patients with T2DM and AH

\begin{tabular}{|l|c|c|c|c|}
\hline \multicolumn{1}{|c|}{ Groups } & \multicolumn{2}{c|}{ ACIV IgA (ng/ml) } & Group 2 & All diabetics \\
\hline & Mean \pm SD & Group 1 & NS & - \\
\hline All diabetics & $0.15 \pm 0.03$ & NS & NS & NS \\
\hline Group 1 & $0.13 \pm 0.02$ & - & - & NS \\
\hline Group 2 & $0.11 \pm 0.07$ & NS & NS & NS \\
\hline Controls & $0.17 \pm 0.06$ & NS & \\
\hline
\end{tabular}




\section{REFERENCES:}

1. Di Mario U, Pugliese G. 15th Golgi lecture: from hyperglycemia to the dysregulation of vascular remodelling in diabetes. Diabetologia. 2001 Jun;44(6): 674-692. [PubMed] [CrossRef]

2. Toeller M, Buyken AE, Heitkamp G, Berg G, Scherbaum WA. Prevalence of chronic complications, metabolic control and nutritional intake in type 1 diabetes: comparison between different European regions. EURODIAB Complications Study group. Horm Metab Res. 1999 Dec;31(12): 680-685. [PubMed] [CrossRef]

3. Krolewski AS, Warram JH, Rand LI, Kahn CR. Epidemiological approach in the etiology of type 1 diabetes mellitus and its complications. $N$ Engl J Med. 1987 Nov 26;317(22):1390-1398. [PubMed] [CrossRef]

4. Hanefeld M, Fisher S, Julius U, Schulze J, Schwanebeck U, Schmechel $\mathrm{H}$, et al. The DIS Group. Risk factors for myocardial infarction and death in newly detected NIDDM: Diabetes International Study, 11-year follow-up. Diabetologia. 1996 Dec;39(12):15771583. [PubMed]

5. Paulsson M. Basement membrane proteins: structure, assembly, and cellular interactions. Crit Rev Biochem Molec Biol. 1992 27(1-2):93-127. [PubMed]

6. Kьhn K, Basement membrane (type IV) collagen. Matrix Biol. 1995 Feb;14(6): 439-45. Review. [PubMed] [CrossRef]

7. Rosenbloom J, Abrams WR, Mecham R. Extracellular matrix 4: the elastic fiber. FASEB J, 1993

8. Schuppan D, Riecken EO. Molecules of the extracellular matrix: potential role of collagens and glycoproteins in intestinal adaptation. Digestion. 1990;46(Suppl 2):2-11. [PubMed]

9. Balashova L, Zaitseva N, Teplinskaia L, Koval'chuk L, Gankovskaia L, Obraztsova E, Aronskind M. Antitela k kollagenu II i IV tipov, faktor nekroza opukholi al'fa i tsirkuliruiushchie immunnye kompleksy v sleze i syvorotke krovi u bol'nykh s razlichnymi stadiiami diabeticheskoi angioretinopatii. Vestn Oftalmol 2000; 116, 31-34. [in Russian]

10. Nicoloff G, Baydanoff S, Petrova Ch, Christova P. Serum antibodies to collagen type IV and development of diabetic vascular complications in children with Type 1 (insulin-dependent) diabetes mellitus - a longitudinal study. Vascular Pharmacology. 2002 Mar;38(3):143-147. [PubMed] [CrossRef]

11. Risteli L, Risteli J. Analysis of extracellular matrix proteins in biological fluids. Methods Enzymol. 1987; 145:391-411. [PubMed]

12. Alland A, Hartmann DJ, Loupy G, Lechevalier D, Ville G, Cotisson A, et al. Etude de la fibronectine et ducollagene de type IV plasmatiques chez le diabetique. Path.Biol. (Paris). 1984 Feb;32(2):115-121. [Article in French] [PubMed]

13. Matsumoto E, Matsumoto G, Bessho H, Kikuoka H, Nanjo K. Serum concentrations of intact type IV collagen in diabetics. J Diabet Complications. 1991; 5:189-190

14. Nicoloff G, Baydanoff S, Stanimirova N, et al. Serum collagen type IV in healthy children and children with insulin-dependent diabetes mellitus. Clin. Appl. Immunol. Invest. 2001; 1:165-168.

15. Hasslacher C, Brocks D, Mann $\mathrm{J}$, Waldherr R. Influence of hypertension on serum concentration of type IV collagen antigens in streptozotocin-diabetic and nondiabetic rats. Diabetologia. 1987 May;30(5):344-347. [PubMed]

16. Yano Y, Ura H, Sumida Y, Gabazza EC, Misaki M, Shima T. Serum 7S domain of type IV collagen levels in essential hypertension and hypertensive type 2 diabetic patients. Diabet Med. 1997 Jun; 14(6):466-71. [PubMed]

17. Kannel WB, McGee DL. Diabetes and cardiovascular risk factors: the Framingham study.
Circulation. 1979 Jan;59(1):8-13. [PubMed] [CrossRef]

18. Moreland LW, Gay RE, Gay S. Collagen autoantibodies in patients with vasculitis and systemic lupus erythematosus. Clin Immun Immunopathol. 1991 Sep;60(3):412-418. [PubMed]

19. Yang CL, Brinckmann J, Rui HF, Vehring K, Lehmann H, Kekow J, et al. Autoantibodies to cartilage collagens in relapsing polychondritis. Arch Dermatol Res. 1993; 285(5):245-249. [PubMed]

20. Susumu T, Uchugu T, Shoichi T, Measurement of Serum Anti-type IV Collagen Antibody in Diabetic Patients, Annals of Gunma University School of Health Sciences, V24.;87-91(2003)

21. Nicoloff G, Angelova M, Christova I, Nikolov A, Alexiev A. Serum cobalt in children with essential hypertension, Am J Hum Biol. 2006 Nov-Dec;18(6):798-805. [PubMed] [CrossRef]

22. Daskalova M, Taskov H, Dimitrova E, Baydanoff S. Humoral and cellular immune response to elastin in patients with systemic sclerosis. Autoimmunity. 1997; 25(4):233-241. [PubMed]

23. Sato Y, Kataoka K, Matsumori A, Sasayama S, Yamada T, Ito H, et al. Measuring serum aminoterminal type III procollagen peptide, $7 \mathrm{~S}$ domain of type IV collagen, and cardiac troponin $\mathrm{T}$ in patients with idiopathic dilated cardiomyopathy and secondary cardiomyopathy. Heart. 1997 Nov;78(5):505508. [PubMed]

24. Kaiser WJ, Holbrook LM, Tucker KL, Stanley RG, Gibbins JM. A functional proteomic method for the enrichment of peripheral membrane proteins reveals the collagen binding protein Hsp47 is exposed on the surface of activated human platelets. $J$ Proteome Res. 2009 Jun;8(6):2903-14. [PubMed] [CrossRef]

25. Ameye LG, Deberg M, Oliveira M, Labasse A, Aeschlimann JM, Henrotin Y. The chemical biomarkers 
C2C, Coll2-1, and Coll2-1NO2 provide complementary information on type II collagen catabolism in healthy and osteoarthritic mice. Arthritis Rheum. 2007 Oct;56(10):3336-46. [PubMed] [CrossRef]

26. Rinaldi N, Willhauck M, Weis D, Brado B, Kern P, Lukoschek M, et al. Loss of collagen type IV in rheumatoid synovia and cytokine effect on the collagen type-IV gene expression in fibroblast-like synoviocytes from rheumatoid arthritis. Virchows Arch. 2001 Nov;439(5):675-82. [PubMed] [CrossRef]

27. Klein R, Klein BE, Moss SE, Davis MD, DeMets DL. The Wisconsin epidemiological study of diabetic retinopathy. II. Prevalence and risk of diabetic retinopathy when age at diagnosis is less than 30 years. Arch Ophthalmol. 1984 Apr;102(4):520-526. [PubMed]
28. Brownlee M, Pongar S, Cerami A. Covalent attachment of soluble proteins by nonenzymatically glycosylated collagen. Role in the in situ formation of immune complexes. $J$ Exp Med. 1983 Nov 1;158(5):1739-1744. [PubMed]

29. Brownlee M. Glycation products and the pathogenesis of diabetic complications. Diabetes Care. 1992 Dec; 15(12):1835-1843. [PubMed]

30. Airaksinen KE, Salmela PI, Linnaluto MK, Ikaheimo MJ, Ahola K, Ryhanen LJ. Diminished arterial elasticity in diabetes: association with fluorescent advanced glycosylation end products in collagen. Cardiovasc Res. 1993 Jun;27(6): 942-945. [PubMed] [CrossRef]

31. Steiner G. Diabetes mellitus, dyslipoproteinaemias and atherosclerosis. Diabetologia. 1997 Jul; 40(Suppl. 2):S147-148. [PubMed]
32. Peterszegi G, Mandet $C$, Texier S, Robert L, Bruneval P. Lymphocytes in human atherosclerotic plaque exhibit the elastin-laminin receptor: potential role in atherogenesis. Atherosclerosis. 1997 Nov; 135(1):103 -107. [PubMed]

33. Peterszegi G, Texier S, Robert L. Human helper and memory lymphocytes exhibit an inducible elastin-laminin receptor. Int Arch Allergy Immunol. 1997 Nov;114(3):218223. [PubMed]

34. Tisheva S. Clinical importance of immunological changes in elastin and collagen turnover in vessel wall in arterial hypertension. Dissertation for acquiring scientific-educational degree „Doctor “, 2004

35. Mekenyan E. Changes of elastin and collagen turnover in development of early cardiovascular complications in patients with metabolic syndrome. Dissertation for acquiring scientificeducational degree „Doctor“, 2012.

\section{Corresponding author:}

Dr. Asparuh Nikolov,

Department of Propedeutics of Internal Diseases, Medical University

91, Vladimir Vazov Str., 2nd Clinical Base, 5800 Pleven, Bulgaria

Tel.: +359/887 100672

E-mail: a_nicoloff@yahoo.com; 